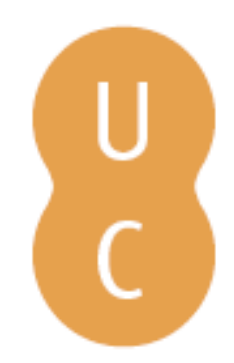

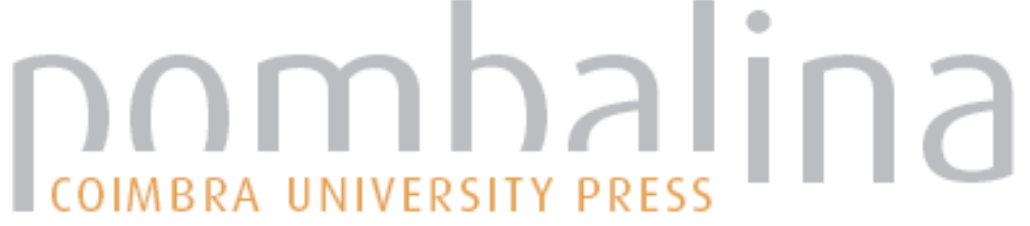

\section{The integration of the law in a politically fragmented world}

\author{
Autor(es): Dallari, Pedro \\ Publicado por: Imprensa da Universidade de Coimbra \\ URL \\ persistente: \\ URI:http://hdl.handle.net/10316.2/43157 \\ DOI: \\ DOI:https://doi.org/10.14195/978-989-26-1433-5_2
}

Accessed : $\quad$ 26-Apr-2023 14:50:38

A navegação consulta e descarregamento dos títulos inseridos nas Bibliotecas Digitais UC Digitalis, UC Pombalina e UC Impactum, pressupõem a aceitação plena e sem reservas dos Termos e Condições de Uso destas Bibliotecas Digitais, disponíveis em https://digitalis.uc.pt/pt-pt/termos.

Conforme exposto nos referidos Termos e Condições de Uso, o descarregamento de títulos de acesso restrito requer uma licença válida de autorização devendo o utilizador aceder ao(s) documento(s) a partir de um endereço de IP da instituição detentora da supramencionada licença.

Ao utilizador é apenas permitido o descarregamento para uso pessoal, pelo que o emprego do(s) título(s) descarregado(s) para outro fim, designadamente comercial, carece de autorização do respetivo autor ou editor da obra.

Na medida em que todas as obras da UC Digitalis se encontram protegidas pelo Código do Direito de Autor e Direitos Conexos e demais legislação aplicável, toda a cópia, parcial ou total, deste documento, nos casos em que é legalmente admitida, deverá conter ou fazer-se acompanhar por este aviso. 


\section{Euro-Atlântico:}

\section{Espaço de Diálogos}

Isabel Maria Freitas Valente

Iranilson Buriti de Oliveira

(Coord)

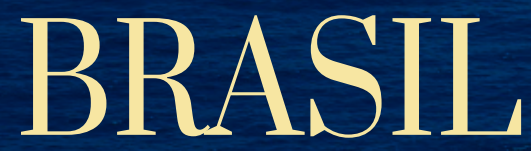

NAS ONDAS

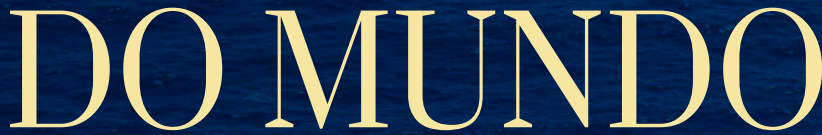

Álvaro Vasconcelos (Org)

Editora da Universidade Federal de Campina Grande

Imprensa da Universidade de Coimbra

2017 
THE INTEGRATION OF THE LAW

IN A POLITICALLY FRAGMENTED WORLD*

Pedro Dallari, PhD

USP-IRI

E-mail: pdallari@usp.br

\begin{abstract}
It is currently consensual the evaluation that the contemporary world is politically fragmented, and that there is no country or international organization that gives broad direction to the international affairs. This evaluation is usually automatically transferred to the understanding of the field of law, which is considered highly fragmented, because both the existence of more than two hundred national legal systems, and the lack of coordination and effectiveness of international law. If it is true that the international political scene is fragmented, this automatic correlation with the field of law is not justified. This is due to the fact that the law has been presenting at the global level, since the mid-twentieth century, a clear tendency towards integration and also to uniformization, as a result of various mechanisms of compatibility of different national and international legal systems.
\end{abstract}

Keywords: international law; integration and uniformization of the law; human rights; global legal order

* A first version of this article was presented orally at the $\mathrm{V}$ Baku International Humanitarian Forum held in September 2016 in Azerbaijan. 
It is currently consensual the evaluation that the contemporary world is politically fragmented, and that there is no country or international organization that gives broad direction to the international affairs. This evaluation is usually automatically transferred to the understanding of the field of law, which is considered highly fragmented, because both the existence of more than two hundred national legal systems and the lack of coordination and effectiveness of international law.

If it is true that the international political scene is fragmented, this automatic correlation with the field of law is not justified. This is due to the fact that the law has been presenting at the global level, since the mid-twentieth century, a clear tendency towards integration and also uniformization, as a consequence of the different legal compatibilization mechanisms among national and international legal systems. And this perspective results from the widespread recognition of the centrality of human beings and their fundamental rights in the structure of the legal order of the contemporary world, which reflects, in the field of law, the impact of the advent of the Anthropocene, the new geological age to which mankind is entering, and whose identification by science comes precisely from the perception of the transforming effects of human activity on the physical structure of the earth. More than strengthening some specialties - such as environmental law, for example - the logic of the Anthropocene approach, ignoring the political fragmentation, leads to the structuring of one legal global order in which the different systems are progressively integrating, in a clear tendency towards uniformization. In this process, however, flexibility and the respect for cultural diversity must be considered, at the risk of lacking legitimacy and functionality to the legal global order. 


\section{Towards the integration of the law}

This dynamic of integration stems from the historical development of politics and law around the world. Just as the risk of collapse of the European political order imposed in the seventeenth century, structural changes in the system of international relations - establishing the sovereign state as the fundamental gear, whose consent was essential to the very existence of an international legal normativity that affected itself -, the risk of collapse of the global political structure, foreshadowed by the two great wars of the twentieth century, again imposed the change of this system. This time, by reason of the establishment of a supranational legal framework aimed to subordinate the States and the international community as a whole to principles and procedural rules essential for the generation of stability.

If after the First World War, the League of Nations meant the attempt to stabilize the international order by virtue of an initiative which, although formally innovative, was yet based in the precepts of the old Westphalian logic, founded in the absolute sovereignty of States, the extreme situations experienced after just two decades - the horror of the Holocaust and the nuclear bombs that marked World War II - accelerated the process of overcoming that logic, whose inevitability was already determined by the transformations underway in the global social and economic relations that came from the beginning of the twentieth century.

In the subsequent years, even with the bipolarity of the Cold War that addressed the international relations for about four decades - giving to the United States and to the Union of Soviet Socialist Republics (USSR), a leading role in the conduct of the international life - it happened the gradual formation, in the light of the new paradigm represented by the United Nations Charter, of a comprehensive legal framework of institutions, principles and rules clearly grounded in the perspective of supranationality. The end of the Cold War and of the subsequent American absolute hegemony made this situation even more accentuated. 
This movement finds in the social sciences a multiplicity of explanations, whose assessment is beyond the scope of this article, but which, in most cases, tends to identify the global integration of production, trade and consumption of goods and services as the most important element. Under a more realistic perspective, the changes were associated with the impact of scientific evolution and technological revolution occurred in the twentieth century and that gained extraordinary propulsion in its second half, leading to the accentuation of economic globalization and of the individual empowerment for autonomous action in international society, but also to the environmental stress and the related risk of elimination of the conditions for preservation of humanity.

In the globalized world, the possibility of a legal framework for human action and correspondent effects, based on the mere sum of exclusive and differentiated national legal orders has proved to be impracticable. How could be possible to deal with acts and relationships increasingly endowed with the attribute of internationality on the basis only of a national law, or even on the sum of different national legal orders? And, on the other hand, how to legally equate within the narrow limits of State borders phenomena that impact human rights and the environment in a varied and wide way? Evolving from the context of the period between the two world wars, it became essential - not just convenient - the establishment of a global legal order dedicated not only to regulate the coexistence of States and their legal systems, but also for the establishment of universal paradigms for the conduct of human life.

\section{The foundation of the global legal order}

The global legal order has been shaped through progressive harmonization among national orders, and also and mainly by the adoption, directly or indirectly, of the criteria stipulated in international law by mandatory rules or soft law. The acceptance of this dynamic related to the building of universal legal paradigms - already present in the law of cooperation, emerged from the advent of the League of Nations - has 
become indispensable for the preservation of the State's capacity to provide the conditions for the exercise of social life by its population. Previously, the justification for the isolated production of legal rules forged to guide social life, the attribute of sovereignty became the enabling factor for the State's participation in the multilateral process of shaping the global legal order.

In this legal order universally designed, the State is not the fundamental unit to which its nationals would merely be subordinated. The very individual - owner of fundamental rights that are recognized universally and that give support to the existence of modern international law - is the basic systemic unit of the global legal order, being the State only an intermediary institution. The State, both producing the rules of national law as well as contracting rules of international law, regulates functionally the integration of the national society to a legal order that has been established globally. However, this integrationist movement should not be understood as a mechanical practice of adhesion to internationally established paradigms. As an intermediate entity for the compatibility between the interests of the national society and those of universal level, the State interacts politically with their counterparts and with international organizations, in a relationship often conflictual, in which respect for cultural diversity must be guaranteed. The global character of this new legal order has not removed the elements of dispute and negotiation that are inherent to all normative production process.

Comparing with the classical theoretical perspective that established the consent of the State as the foundation of the international law, contemporarily the State consent indeed remains as an operational factor and criterion of legitimacy, but no longer as its foundation. This does not mean the cease of State's political activity - the State is still the main entity in the conduction of international relations. Nevertheless both the political activity that happens internally as that one related to foreign relations cannot deny and neither prevent the expansion of international law and the structuring of the global legal order. 


\section{The relevance of international law}

In the context of building up the global legal order, although its configuration is already clear from the trend towards uniformization between the different national legal systems, the most important role belongs to the international law and related institutions. The international rules that form the international law, on one side significantly influence this unifying perspective of the law of the States and on the other, being endowed themselves of cogency and effectiveness, gradually occupy the regulatory space for the guidance of social life previously filled exclusively by rules arising out of national law.

In the evolution of international law throughout the twentieth century, from its initial characterization as the law of coexistence, which applied to the international society of States until the First World War, it became the law of cooperation, characteristic of the international community of States inaugurated with the League of Nations. And from the end of World War II it has been transforming into the law of the human community, shaped in the political order established with the United Nations and aimed to rule the community comprising all human beings.

The notions of society and community have many and varied meanings, including as regards the application of the terms into the international dimension. Notwithstanding, in general, it is recognized that a community is identified based on a common cultural heritage, embodied in self-applicable principles and rules of conduct, that put it beyond a society, which is determined just by a formally established link. A society is characterized by the mere coexistence of its members in a given formal space - more often a delimited territory - while a community, which can even exist without institutional setting or territorial delimitation, is based in a qualitatively distinct link between their members, supported by a common behavioral ethics.

In the application of such more general and common meanings to the field of international law, the normative framework of a situation of mere coexistence among States, characteristic of the legal system prevailing 
until the First World War, could be seen as intended to set up an international society composed of those States, in which international rules - arising from the situation expressed by the Latin aphorism ubi societas ibi jus ("if there is society, there is law") - tried to discipline strictly the issues necessary to the feasibility of coexistence, as the demarcation of border lines. In the context of the law of cooperation - arising, as seen, with the order represented by the League of Nations -, to the extent that the exercise of cooperation demanded the existence of common elements concerning the organization and functioning of each of the cooperating States, this identity has given rise to the perception of an international community of States. With the overcoming of State consent as the theoretical foundation of international law, it is today outlined the law of the buman community, which, in turn, is based ultimately in the attributes common to all individuals, legally expressed in the universal dimension of fundamental human rights. With this perspective of the law of the human community, international law rescue the literal sense of the expression jus gentium, or the law of people, which was salvaged from the Roman law and that had been used at the beginning of the doctrinal process of structuring and knowledge of this field of the law.

This integrative perspective of the law in a legal order that, under the guidance of international law, is gaining a universal profile has a relevant example in the field of human rights. International human rights law, which has its fundamental landmark in the Universal Declaration of Human Rights adopted by the United Nations General Assembly in 1948, have since expanded rapidly and substantially, based on a strong framework of international treaties and institutions dedicated to the monitoring and control of State actions in this field, including judicial courts. In addition to this progressive solidification of a specific structure, international human rights law has been significantly adopted as a parameter for the regulation of its subjects at the level of national legislation, thus generating a clear uniformization scenario. 
In the process of drafting the Brazilian Constitution adopted in 1988, this situation became evident. The Constitution contains a large number of provisions directly inspired by the Universal Declaration and some of the main human rights treaties, as the International Covenant on Civil and Political Rights and the International Covenant on Economic, Social and Cultural Rights, both adopted by the UN in 1966, and the 1969 American Convention on Human Rights (Pact of San José). It should be noted that the declaration has not a treaty nature, and is therefore not formally binding on the Brazilian State, and that the three covenants, although prior to the Constitution, had not yet been the subject of Brazil's accession, what happened only in 1992. Nevertheless, in clear expression of the phenomenon of soft law, these documents greatly influenced the constituent process, either directly or through consideration of provisions of the same inspiration present in the constitutions of Spain and Portugal originating from the respective democratizing processes of the 1970s.

\section{The configuration of the international community of human beings}

The progressive conformation of the global legal order - in which leading role belongs to international law, with its current feature of the law of the human community - is not, of course, the reason for the configuration of this international community formed by the human beings. On the contrary, this movement in the sphere of law only reflects a transformative process of social nature, whose effects on the political and economic areas are guiding the setting of new legal forms. The genesis of the international system of protection of human rights, after the institution of the United Nations, and the rapid and extraordinary progress in the structuring of this system - certainly driven also by the impact of the tragic events of World War II - are actually the consequence of the necessary adaptation of international law to the social, political e economical changes that led the human being to the condition of fundamental systemic unit of the international legal framework. Nevertheless, this new legal reality, in turn, as it will strengthen, shall constitute an element of 
the social structure from which it is derived and therefore has strong influence over the evolution of this same social structure towards the consolidation of a universal community of human beings. The legal fact is a social fact, and as such, it reflects and influences the social change.

It should be noted that this evolutionary movement toward the setting up of a comprehensive legal order obviously has not been given linearly. This is a consistent trend that has been extracted from a scenario that includes, in the field of international relations and even internally at the States, political events that sometimes support it and sometimes repudiate it, but in the long term of history, preserve it and highlight it. This pattern of evolution is not therefore a rail that guides and subordinates the ongoing changes, but actually a description that reflects a general tendency. 